\title{
Exercise stress CMR in patients with coronary heart disease - preliminary results
}

\author{
Agnes Mayr ${ }^{1 *}$, Markus Holotta ${ }^{1}$, Regina Esterhammer ${ }^{1}$, Klemens Mairer $^{1}$, Gert Klug$^{2}$, Hans-Josef Feistritzer ${ }^{2}$, \\ Bernhard Metzler ${ }^{2}$, Michael Schocke ${ }^{1}$
}

From 18th Annual SCMR Scientific Sessions

Nice, France. 4-7 February 2015

\section{Background}

Cardiac stress MRI has grown to a well established method to detect hypokinesia or perfusion deficits due to ischemia. Commonly, myocardial load is generated by the administration of adenosine or dobutamine, which is associated by a higher complication rate compared to exercise stress testing. Our purpose was to evaluate the use of an MR conditional pedal ergometer for cardiac stress MRI.

\section{Methods}

We included 15 patients with coronary heart disease until now. All patients underwent exercise stress MRI at a whole-body 3 Tesla MR system and received real-time TRUFI CINE imaging and first-pass perfusion imaging before and after stress testing as well as late enhancement (LE) PSIR sequences after stress. All images were visually rated by three experienced radiologists.

\section{Results}

As shown on LE images, two patients suffered from silent myocardial infarction and showed stress-induced hypokinesia and slight perfusion deficits nearby the infarction scar. In additional 5 patients, we detected segmental hypokinesia and endocardial perfusion deficits due to exercise. 3 patients exhibited endocardial perfusion deficits without hypokinesia. 5 patient did not show any abnormalities due to stress.

\section{Conclusions}

Exercise stress of the myocardium is a helpful method to detect ischemic area in cardiac MRI.

\section{Funding}

Nothing to declare.

\section{Authors' details}

'Radiology, Medical University Innsbruck, Innsbruck, Austria. ${ }^{2}$ Cardiology, Medical University Innsbruck, Innsbruck, Austria.

Published: 3 February 2015

doi:10.1186/1532-429X-17-S1-P125

Cite this article as: Mayr et al.: Exercise stress CMR in patients with coronary heart disease - preliminary results. Journal of Cardiovascular Magnetic Resonance 2015 17(Suppl 1):P125.
Submit your next manuscript to BioMed Central and take full advantage of:

- Convenient online submission

- Thorough peer review

- No space constraints or color figure charges

- Immediate publication on acceptance

- Inclusion in PubMed, CAS, Scopus and Google Scholar

- Research which is freely available for redistribution
() Biomed Central
C Biomed Central

(c) 2015 Mayr et al; licensee BioMed Central Ltd. This is an Open Access article distributed under the terms of the Creative Commons Attribution License (http://creativecommons.org/licenses/by/4.0), which permits unrestricted use, distribution, and reproduction in any medium, provided the original work is properly cited. The Creative Commons Public Domain Dedication waiver (http:// creativecommons.org/publicdomain/zero/1.0/) applies to the data made available in this article, unless otherwise stated. 